\title{
Gastrointestinal stromal tumors express the orexigen ghrelin
}

\author{
Sara Ekeblad, Bengt Nilsson ${ }^{1}$, Margareta Halin Lejonklou, Térèse Johansson, \\ Peter Stålberg ${ }^{2}$, Ola Nilsson ${ }^{3}$, Håkan Ahlman ${ }^{1}$ and Britt Skogseid
}

\author{
Department of Medical Sciences, University Hospital, 75185 Uppsala, Sweden \\ ${ }^{1}$ Department of Surgery, Sahlgrenska University Hospital, 41345 Göteborg, Sweden \\ ${ }^{2}$ Department of Surgical Sciences, University Hospital, 75185 Uppsala, Sweden \\ ${ }^{3}$ Department of Pathology, Sahlgrenska University Hospital, 41345 Göteborg, Sweden \\ (Requests for offprints should be addressed to B Skogseid; Email: britt.skogseid@medsci.uu.se)
}

\begin{abstract}
Expression of the neuroendocrine marker synaptic vesicle protein 2 (SV2) has been reported in a few cases of gastrointestinal stromal tumors (GISTs). The goal of the present study was to assess the relevance of this finding and identify a possible hormone production in these tumors. We chose to study the orexigen ghrelin and its receptor, since these patients are seldom cachexic, even in advanced disease stages. We investigated ghrelin expression by means of immunohistochemistry on frozen or paraffin-embedded sections from 22 GISTs from a well-characterized patient material. Expression of the growth hormone secretagogue receptor, the ghrelin receptor, was investigated in a subset of lesions. In six tumors, mRNA levels of ghrelin, the ghrelin receptor, and SV2 were analyzed by real-time quantitative PCR. Totally 17 out of 22 tumors showed immunoreactivity for ghrelin. Five out of ten tumors were immunoreactive for the ghrelin receptor, and all of these co-expressed ghrelin. All tumors expressed ghrelin, ghrelin receptor, and SV2 mRNA. GISTs frequently express SV2, ghrelin, and its receptor, indicating the presence of autocrine/paracrine loops.
\end{abstract}

Endocrine-Related Cancer (2006) 13 963-970

\section{Introduction}

Gastrointestinal stromal tumors (GISTs) originate from pacemaker cells (the interstitial cells of Cajal) and therefore exhibit a phenotype with expression of CD34 and the KIT tyrosine kinase receptor (Kindblom et al. 1998, Sarlomo-Rikala et al. 1998, Corless et al. 2004). Activating KIT mutations are seen in a majority of GISTs (Hirota et al. 1998), most commonly in exon 9 or 11. Subsets of GISTs can have mutations in the KITrelated kinase gene PDGFRA (Corless et al. 2004).

Patients with neurofibromatosis-1 (NF-1) have an increased risk of developing GIST, and in a populationbased consecutive series of 259 patients with GIST (1983-2000), four patients had NF-1 and five other patients harbored concomitant neuroendocrine tumors (Nilsson et al. 2005). Mutations of NF-2 have been reported in single cases of GIST (Fukasawa et al. 2000). GIST can also occur with paraganglioma and pulmonary chondroma in the setting of Carney triad (Carney et al. 1977, Bumming et al. 2006).
Clinically, GISTs range from small, indolent, surgically curable tumors to very aggressive tumor disease. Histopathologically, they are composed of spindled or epithelioid cells, or are of a mixed type. According to a recently suggested classification, the risk of malignancy can be estimated based on tumor size and mitotic count (Fletcher et al. 2002). Until recently, surgery was the only effective treatment, with poor outcome for high-risk patients (DeMatteo et al. 2000). With the introduction of selective tyrosine kinase inhibitors, the medical treatment of patients with advanced GIST harboring KIT or PDGFRA mutations has markedly improved (Bumming et al. 2003, Corless et al. 2004).

Patients with GIST are, unlike other patients with malignant abdominal tumors, seldom cachexic, even in advanced stages of disease (personal experience). A similar relative well-being can also be seen in patients with endocrine pancreatic tumors (EPT), which recently were shown to express ghrelin, a potent 
orexigenic hormone (Iwakura et al. 2002, Volante et al. 2002, Corbetta et al. 2003, Rindi et al. 2004).

Ghrelin, a 28-amino acid peptide discovered in 1999, is expressed mainly in the gastric endocrine A cells, and also in other tissues, e.g., intestine, pancreas, kidney, liver, and hypothalamus (De Ambrogi et al. 2003). Ghrelin is a natural ligand of the growth hormone secretagogue receptor (GHS-R) and stimulates growth hormone release. It increases appetite and reduces fat utilization when given systemically or into the brain of rodents (Tschop et al. 2000). Levels are high in fasting individuals and fall upon intake of food. Obese individuals have lower circulating ghrelin levels compared to lean. Expression of ghrelin and its receptor have previously been shown in testicular, breast, and prostate cancer, as well as in pancreatic and other neuroendocrine tumors. Accordingly, an autocrine/ paracrine role of ghrelin has been suggested (Jeffery et al. 2003). A ghrelinoma syndrome has not yet been characterized.

Interstitial cells of Cajal have been reported to express cholecystokinin and somatostatin receptor subtypes (Sternini et al. 1997, Patterson et al. 2001). Recently, GISTs were shown to express high numbers of other peptide hormone receptors, e.g., bombesin subtype 2 and vasoactive intestinal peptide subtype 2 receptors (Reubi et al. 2004). The neuroendocrine marker synaptic vesicle protein 2 (SV2) (PortelaGomes et al. 2000) has been reported in eight cases of GIST (Jakobsen et al. 2002). Furthermore, one patient with an insulin-like growth factor-II producing GIST has been reported with symptoms of hypoglycemia (Beckers et al. 2003). In this paper, we share our data on expression of the orexigen ghrelin and its receptor, as well as SV2 mRNA, in GISTs.

\section{Materials and methods}

\section{Tumor material}

GISTs from 22 patients were studied. Tumors were located in the stomach $(n=8)$, duodenum $(n=3)$, small intestine $(n=9)$, and rectum $(n=2)$; were of spindled $(n=10)$, epithelioid $(n=10)$, or mixed type $(n=2)$, and displayed KIT immunoreactivity. Due to limited availability, the tumor material was retrieved from both paraffin-embedded blocks $(n=12)$ and fresh frozen surgical specimens $(n=10)$.

All tumors were examined histopathologically regarding size, growth pattern (spindled, epithelioid, and mixed), mitotic rate (mitoses per high power field,

Table 1 Patient data and results of ghrelin and ghrelin receptor staining of GISTs

\begin{tabular}{|c|c|c|c|c|c|c|c|c|c|}
\hline Age/sex & $\begin{array}{l}\text { BMI } \\
\text { preop. }\end{array}$ & $\begin{array}{l}\text { Tumor } \\
\text { site and } \\
\text { size }(\mathrm{cm})\end{array}$ & $\begin{array}{l}\text { Tumor } \\
\text { type }\end{array}$ & $\begin{array}{l}\text { Ki } 67 \% / \\
\text { mitotic } \\
\text { rate }\end{array}$ & Risk score & $\begin{array}{l}\text { Kit } \\
\text { exon } 11 \\
\text { mutation }\end{array}$ & $\begin{array}{l}\text { Distant } \\
\text { metastases at } \\
\text { diagnosis }\end{array}$ & $\begin{array}{l}\text { Ghrelin } \\
\text { IHC }\end{array}$ & $\begin{array}{l}\text { Receptor } \\
\text { IHC }\end{array}$ \\
\hline $56 / \mathrm{M}$ & 21.4 & $\mathrm{SB} / 20$ & Mixed & $10 / 2-5$ & High & Yes & Liver & - & - \\
\hline $56 / \mathrm{M}$ & ND & $\mathrm{R} / 4.5$ & Spindled & $5 /<2$ & Low & Yes & - & - & - \\
\hline $74 / \mathrm{M}$ & 26.6 & $\mathrm{D} / 11$ & Epithelioid & $25 / 6-11$ & High & No & - & ++ & ++ \\
\hline 63/M & 25.3 & $\mathrm{~S} / 16$ & Epithelioid & $1 /<2$ & High & Yes & Liver & - & - \\
\hline $57 / M$ & 27.6 & SB/29 & Mixed & $30 />10$ & High & Yes & Peritoneal & + & - \\
\hline $15 / F$ & 22.9 & $\mathrm{~S} / 7$ & Epithelioid & $<5 / 2-5$ & Intermediate & No & - & ++ & +++ \\
\hline $70 / \mathrm{M}$ & 22.1 & $\mathrm{D} / 25$ & Spindled & $25 / 6-10$ & High & No & Liver & ++ & + \\
\hline $48 / \mathrm{M}$ & 30.1 & $\mathrm{R} / 9$ & Spindled & $10 / 2-5$ & Intermediate & Yes & - & ++ & + \\
\hline $55 / \mathrm{M}$ & ND & $\mathrm{SB} / 15$ & Epithelioid & $>10 / 2-5$ & Intermediate & Yes* & Liver, peritoneal & + & - \\
\hline $58 / \mathrm{M}$ & ND & $\mathrm{SB} / 4.5$ & Spindled & $<5 /<1$ & Low & Yes & - & ++ & ND \\
\hline $45 / \mathrm{M}$ & 26.3 & $\mathrm{SB} / 5$ & Spindled & $10 />10$ & High & Yes & - & + & ++ \\
\hline $72 / \mathrm{M}$ & ND & $\mathrm{SB} / 12$ & Spindled & $20 />10$ & High & Yes & Liver & ++ & ND \\
\hline $63 / \mathrm{M}$ & ND & $\mathrm{SB} / 15$ & Epithelioid & $50 / 2-5$ & High & No & - & - & ND \\
\hline $69 / F$ & 24.5 & $\mathrm{SB} / 11$ & Epithelioid & $5 / 2-5$ & High & Yes & - & +++ & ND \\
\hline $73 / F$ & 25.6 & $\mathrm{~S} / 20$ & Epithelioid & $50 />10$ & High & Yes & - & +++ & ND \\
\hline $48 / F$ & 21.8 & $\mathrm{D} / 8$ & Spindled & $50 />10$ & High & Yes & Liver & +++ & ND \\
\hline $77 / F$ & ND & $\mathrm{S} / 4$ & Spindled & $10 / 2-5$ & Intermediate & No & Liver & ++ & ND \\
\hline $27 / M$ & 31.1 & $S / 3.5$ & Epithelioid & $10 / 6-10$ & High & No & - & + & ND \\
\hline $72 / \mathrm{M}$ & ND & $\mathrm{S} / 19$ & Spindled & $25 />10$ & High & Yes & Lung, liver & +++ & ND \\
\hline $72 / F$ & 20.8 & $\mathrm{~S} / 18$ & Epithelioid & $29 / 6-10$ & High & Yes & Liver & + & ND \\
\hline $48 / \mathrm{M}$ & ND & $\mathrm{SB} / 29$ & Spindled & $50 />10$ & High & Yes & Liver & - & ND \\
\hline $80 / \mathrm{M}$ & 25.1 & $\mathrm{~S} / 20$ & Epithelioid & $10 / 6-10$ & High & Yes & Carcinomatosis & +++ & ND \\
\hline
\end{tabular}

IHC, immunohistochemistry; S, stomach; D, duodenum; SB, small bowel; R, rectum; ND, not done; -, no immunoreactivity; BMI, body mass index; preop., preoperatively.

,$+ 1-25 \%$ of cells positive;,$++ 26-75 \%$ of cells positive;,$+++>75 \%$ of cells positive; ${ }^{*}$, exon 9 mutation. 
Table 2 Ghrelin and ghrelin receptor immunoreactive tumors in relation to clinical and morphological features, genotype, and proliferation

\begin{tabular}{|c|c|c|}
\hline Tumor material & $\begin{array}{l}\text { Ghrelin } \\
\text { positive }\end{array}$ & GHS-R ${ }^{a}$ positive \\
\hline Total $(n=22)$ & $17 / 22$ & $5 / 10$ \\
\hline \multicolumn{3}{|l|}{ Tumor type } \\
\hline Spindled $(n=10)$ & $8 / 10$ & $3 / 4$ \\
\hline Epithelioid $(n=10)$ & $8 / 10$ & $2 / 4$ \\
\hline Mixed $(n=2)$ & $1 / 2$ & $0 / 2$ \\
\hline \multicolumn{3}{|l|}{ Location } \\
\hline Stomach $(n=8)$ & $7 / 8$ & $1 / 2$ \\
\hline Duodenum $(n=3)$ & $3 / 3$ & $2 / 2$ \\
\hline Small bowel $(n=9)$ & $6 / 9$ & $1 / 4$ \\
\hline Rectum $(n=2)$ & $1 / 2$ & $1 / 2$ \\
\hline \multicolumn{3}{|l|}{ Size } \\
\hline$<5 \mathrm{~cm}(n=8)$ & $3 / 4$ & $0 / 1$ \\
\hline $5-10 \mathrm{~cm}(n=4)$ & $4 / 4$ & $3 / 3$ \\
\hline$>10 \mathrm{~cm}(n=14)$ & $10 / 14$ & $2 / 6$ \\
\hline \multicolumn{3}{|l|}{ Mitotic index } \\
\hline$\leq 5(n=10)$ & $6 / 10$ & $2 / 6$ \\
\hline $6-10(n=5)$ & $5 / 5$ & $2 / 2$ \\
\hline$\geq 10(n=7)$ & $6 / 7$ & $1 / 2$ \\
\hline \multicolumn{3}{|l|}{$\mathrm{Ki} 67$} \\
\hline$\leq 5(n=5)$ & $3 / 5$ & $1 / 3$ \\
\hline $6-10(n=6)$ & $5 / 6$ & $2 / 3$ \\
\hline$>10(n=11)$ & $9 / 11$ & $2 / 4$ \\
\hline \multicolumn{3}{|l|}{ Risk index } \\
\hline $\operatorname{Low}(n=2)$ & $1 / 2$ & $0 / 1$ \\
\hline Intermediate $(n=3)$ & $3 / 3$ & $2 / 2$ \\
\hline High $(n=17)$ & $13 / 17$ & $3 / 7$ \\
\hline \multicolumn{3}{|l|}{ Exon 11 or 9 mut } \\
\hline Yes $(n=15)$ & $11 / 15$ & $2 / 7$ \\
\hline No $(n=6)$ & $5 / 6$ & $3 / 3$ \\
\hline
\end{tabular}

${ }^{\mathrm{a}}$ Immunohistochemistry for the ghrelin receptor was performed in a subset of lesions $(n=10)$.

assessed in 50 high power fields), and Ki67 index. Furthermore, the tumors were graded as having a very low $(n=0)$, low $(n=2)$, intermediate $(n=3)$, or high risk $(n=17)$ of malignant behavior, according to Fletcher et al. (2002). A summary of tumor characteristics is given in Tables 1 and 2 .

Three tumors had a low mitotic rate $(<2)$, seven displayed a mitotic rate between 2 and 5, and in five tumors the number of mitoses was between 6 and 10 . In the remaining seven tumors, more than ten mitoses per high power field were seen. Five tumors had a low Ki67 index $(<5 \%)$, six tumors had a Ki67 index between 6 and 10\%, and 11 tumors displayed more than $10 \%$ Ki67 immunoreactive cells. Fifteen out of twenty-one analyzed patients had an activating mutation of KIT. Median patient age at diagnosis was 60.5 years (range $15-80$ years, mean 59 years). Median tumor size at diagnosis was $13.5 \mathrm{~cm}$ (range $3.5-29 \mathrm{~cm}$, mean $13.9 \mathrm{~cm}$ ), placing most patients in the high-risk group. Twelve out of twenty-two patients had distant metastases at diagnosis.

\section{Normal tissue material}

Frozen consecutive sections of normal small intestine from a patient with a GIST tumor (patient no. 11) were used.

\section{Immunohistochemistry (IHC)}

Due to a limited availability of tumor tissue, either frozen $(n=10)$ or paraffin-embedded $(n=12)$ sections were used for ghrelin IHC. Staining for the ghrelin receptor was done only on frozen tissue, except in one case where both frozen and paraffin-embedded materials were available. Frozen sections $(6 \mu \mathrm{m})$ were fixed in acetone, and incubated at $4{ }^{\circ} \mathrm{C}$ overnight with rabbit anti-ghrelin (H-031-30, Phoenix Pharmaceuticals, Belmont, CA, USA; 1:2400) or rabbit antiGHS-R (H-80, Santa Cruz Biotechnology, Santa Cruz, CA, USA; 1:200), diluted in PBS with 1\% BSA. The reaction product was visualized using a biotinylated secondary rabbit antibody, VECTASTAIN Elite ABC (Vector, Burlingame, CA, USA) and the chromogen 3-amino-9-ethylcarbazol (Sigma). Counterstaining was done with Mayer's hematoxylin. For antigen retrieval, the paraffin-embedded sections were subjected to pretreatment $(2 \times 5 \mathrm{~min}$ microwave heating at $900 \mathrm{~W}$ in Tris-EDTA at $\mathrm{pH}$ 9). Sections were incubated with rabbit anti-human ghrelin (GHS-11-A, Alpha Diagnostics, San Antonio, TX, USA; 1:50), diluted in antibody diluent (DakoCytomation, Glostrup, Denmark), or goat anti-GHS-R (F-16, Santa Cruz Biotechnology; 1:200), diluted in PBS with $1 \%$ $\mathrm{BSA}$, at room temperature for $2 \mathrm{~h}$. In our hands, these antibodies generated better IHC staining on paraffinembedded tissue compared to the antibodies used on frozen tissue. The reaction product was revealed using the Envision+System with 3,3'-diamino-benzidine (DAB) as chromogen (DakoCytomation). Sections were counterstained with Mayer's hematoxylin. All sections had been stained with anti-Ki67 (M7240, DakoCytomation; 1:100) and anti-KIT (sc-168, Santa Cruz Biotechnology; 1:100). Initial experiments with each antibody were performed with or without the inclusion of primary antibody. A blocking peptide (GHS-11-P, Alpha Diagnostics), $5 \mu \mathrm{g}$ peptide/1 $\mu \mathrm{g}$ antibody, successfully demonstrated the specificity of ghrelin antibody (GHS-11-A) used on paraffinembedded sections (Fig. 1a). All sections were examined by one pathologist and graded as being negative, or having $1-25 \%(+), 26-75 \%(++)$, or more than $75 \%$ positive cells $(+++)$. 

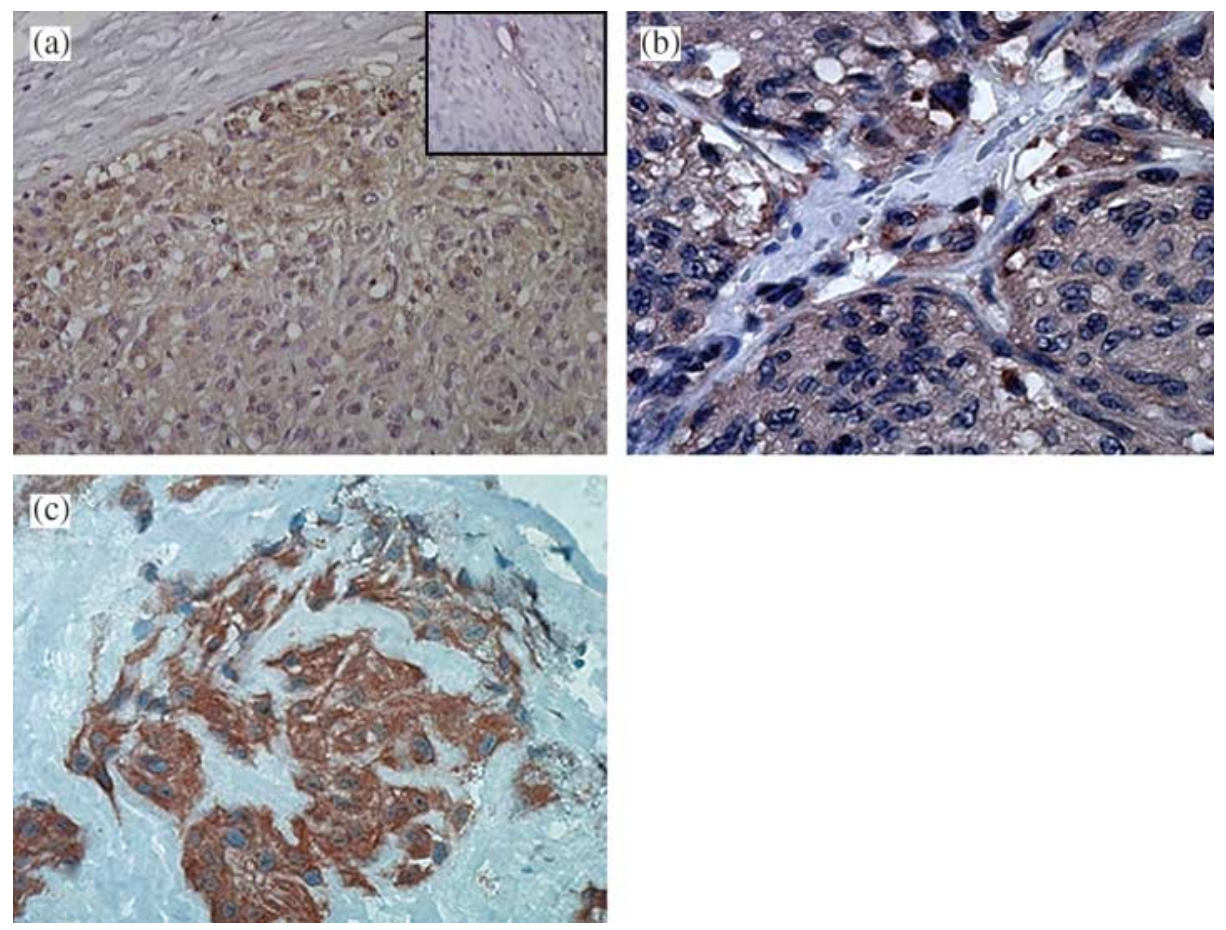

Figure 1 Light microscopy of a tumor (no. 6) showing immunoreactivity for ghrelin (paraffin-embedded tissue, $\times 200)(a)$. The reactivity was abolished by preabsorbing ghrelin anti-serum with an excess of ghrelin peptide (insert). The same tumor was also immunoreactive for the GHS-R (paraffin-embedded tissue, $\times 400)(b)$. Light microscopy of a tumor (no. 10) displaying strong immunoreactivity for ghrelin (frozen tissue, $\times 400)(c)$.

\section{Real-time quantitative PCR (qPCR)}

Total RNA from frozen tumors was isolated using Trizol (Invitrogen) according to the manufacturer's instructions. Consecutive slides were stained with Mayer's hematoxylin and studied with light microscopy to ensure adequate tumor sampling and avoid inclusion of normal tissue.

cDNA was synthesized using the high-capacity cDNA Archive Kit (Applied Biosystems, Foster City, CA, USA). Relative mRNA expression of ghrelin (primer/probe Hs00175082_m1; Applied Biosystems) in six GIST tumors was determined by real-time qPCR, and compared with that of controls (five EPT: one IHC negative, one with single dispersed IHC positive cells, and three IHC positive tumors). Relative mRNA expression of SV2 (primer/probe Hs00372069_m1; Applied Biosystems) was determined in six GIST tumors and compared with that of four EPTs. Relative mRNA expression of the ghrelin receptor (primer/probe Hs0026978_s1; Applied Biosystems) was determined in six GIST tumors, and compared with that of four EPTs (three IHC positive and one negative). Commercially available primer and probe sets spanning exon/exon boundaries were used and measured against standard curves generated from dilution series of human pooled cDNA or human fetal brain cDNA from Human Total RNA Master Panel II (636643; BD Biosciences, San Jose, CA, USA). Reactions were performed and analyzed using an Applied Biosystems PRISM 7700 Sequence Detector. Standard cycling conditions were used (Heid et al. 1996). The gene-specific signals were normalized to that of the $18 \mathrm{~S}$ or HPRT housekeeping genes to correct for differences in RNA quantity. All TaqMan assay reagents were obtained from Applied Biosystems.

\section{Mutation analysis}

Genomic DNA was prepared from paraffin-embedded sections for nucleotide analysis of exons 9 and 11 of KIT. Exon 11 of KIT was amplified by PCR and directly sequenced and cloned, if needed. In summary, nucleotide sequence analyses were made as previously described (Bumming et al. 2003).

\section{Statistical analysis}

The $\chi^{2}$ and one-way ANOVA tests were used; $P<0.05$ was considered significant. 


\section{Body mass index (BMI)}

The BMI was calculated as $\mathrm{kg} / \mathrm{m}^{2}$ when this information was available in the medical records.

\section{Ethical approval}

Permission for this study was obtained from the Ethical Committee, University of Göteborg, Sweden.

\section{Results}

\section{IHC}

Immunoreactivity for ghrelin was detected in 17 out of 22 tumors (Tables 1 and 2; Fig. 1a and c). The reaction product was confined to the cytoplasm and revealed a fine granular pattern. In several tumor samples, the staining was heterogeneous with large areas devoid of ghrelin immunoreactivity and other parts with strong staining. Five out of 17 tumors showed less than 25\% ghrelin-immunoreactive cells. Seven were graded as $++(26-75 \%$ immunoreactive tumor cells), and the remaining five tumors were graded as +++ (more than $75 \%$ immunoreactive tumor cells). Ghrelin immunoreactivity was equally common in spindled, epithelioid, and mixed phenotypes of 8/10, 8/10, and $1 / 2$ respectively. All three duodenal tumors expressed ghrelin immunoreactivity, as did seven out of eight tumors of gastric origin. Six out of nine tumors from the small intestine and one out of two rectal tumors displayed ghrelin immunoreactivity. No correlation was seen between tumor location $(P=0.426)$, size $(P=0.590)$, KIT genotype $(P=0.935)$, and ghrelin expression. Tumors with a mitotic rate of $\leq 5$ expressed ghrelin in six out of ten cases versus all five lesions with a mitotic rate of $6-10$, and six out of seven with a mitotic rate exceeding 10 . However, a mitotic count $>5$ did not correlate significantly with the presence of ghrelin immunoreactivity $(P=0.210)$. Neither did Ki67 index $>5(P=0.659)$. All three tumors classified to be of intermediate risk, and 13 out of 17 high-risk tumors, showed ghrelin immunoreactivity. On the other hand, one out of two low-risk tumors were also immunopositive. Thus, ghrelin immunoreactivity did not show significant correlation with the risk score used $(P=0.420)$.

IHC for the ghrelin receptor was performed on frozen tissue from ten surgical specimens. No correlation was seen between receptor expression and risk score $(P=0.208), \mathrm{Ki} 67$ index $(P=0.717)$, mitotic rate $(P=0.264)$, anatomic site $(P=0.392)$, size $(P=1.000)$, or morphological type $(P=0.223)$. The receptor stained positive in five out of ten GISTs
(Tables 1 and 2; Fig. 1b) and all five receptor-positive tumors showed concomitant ghrelin expression. Two receptor-negative tumors were ghrelin-positive, and three were negative for both the receptor and the ligand.

A thin layer of cells in normal small bowel tissue, situated between the outer and inner intestinal muscle layers, possibly representing interstitial cells of Cajal, showed KIT immunoreactivity. These cells were negative for both ghrelin and its receptor (data not shown).

\section{Real-time qPCR}

Real-time qPCR revealed ghrelin mRNA expression in all six analyzed tumors (Fig. 2a). The mean ghrelin mRNA level in GISTs was similar to that of five EPTs used as controls (one IHC-negative, one with single dispersed IHC-positive cells, and three IHC-positive tumors). Ghrelin receptor mRNA expression was found in all six analyzed GIST lesions, with one tumor expressing much higher levels than the others (Fig. 2b). The mean receptor mRNA level in GISTs was 3.2 times higher (range 0.69-13.6, median 1.1) than controls, which did not constitute a significant difference $(P=0.420)$. RNA levels of ghrelin and its receptor did not correlate to the degree of protein expression detected by IHC. High levels of SV2 mRNA expression were found in all six analyzed tumors (Fig. 3). SV2 mRNA levels in GIST tumors were similar to those of the EPTs used as controls (mean 1.4 times higher, range 0.64-2.0, median 1.6).

\section{BMI}

Data for calculation of BMI were available in 14 patients (Table 1). Mean BMI preoperatively was $25.1 \pm 3.1$ (s.D.) (range 20.8-31.1, median 25.2), i.e. this patient group was slightly overweight according to the international definitions. The corresponding figure for patients with ghrelin-immunoreactive tumors was 25.4 (range 20.8-31.1, median 25.4). More than half of the analyzed GIST patients were overweight (BMI $>$ $25)$, and two patients (14\%) were obese (BMI > 30) (both with ghrelin-immunoreactive tumors). No patient was underweight $(\mathrm{BMI}<20)$.

\section{Discussion}

The present paper is, to our knowledge, the first report of ghrelin production in GISTs. We demonstrate expression of ghrelin and its receptor mRNA in all GISTs analyzed, as well as ghrelin and receptor immunoreactivity in a majority of tumors. We also show high levels of SV2 mRNA, an established marker 


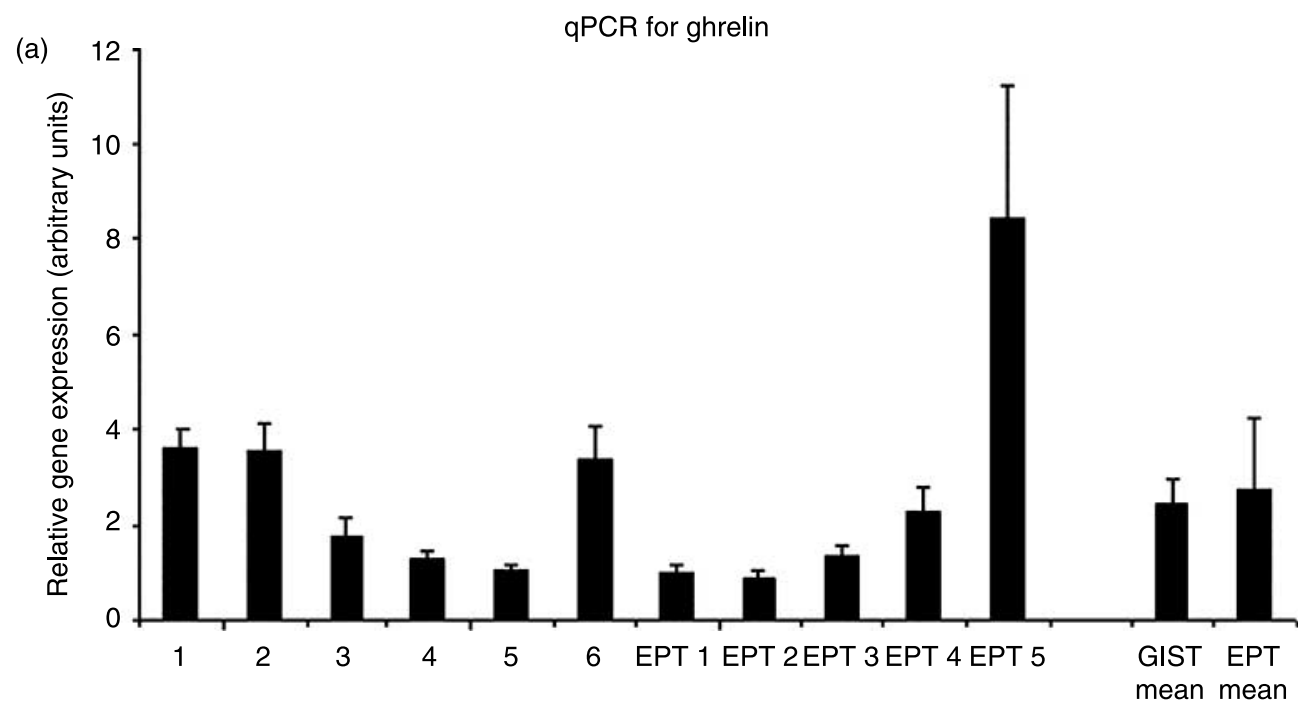

(b)

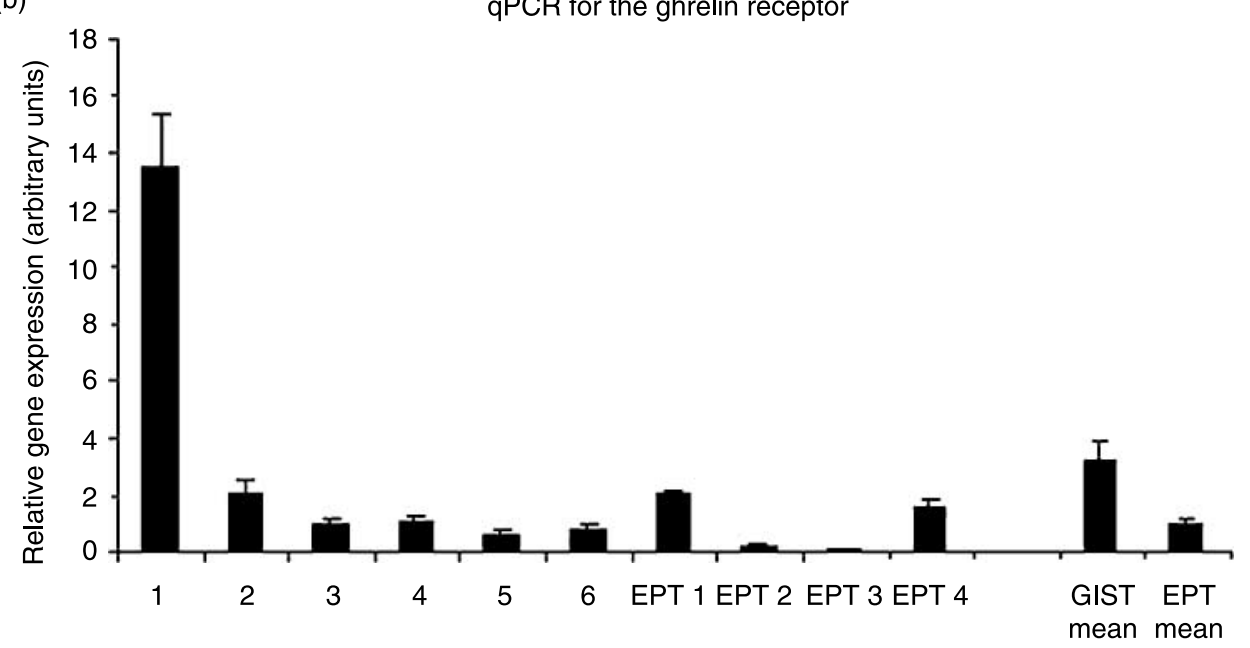

Figure 2 Mean relative gene expression of ghrelin (a) and ghrelin receptor (b) determined with real-time qPCR, \pm S.E.M. The mean ghrelin mRNA level in GISTs was similar to that of five pancreatic endocrine tumors (EPT 1-5) used as controls. The mean receptor mRNA level in GISTs was 3.2 times higher (range 0.69-13.6) versus four EPT (EPT 1-4).

for neuroendocrine cells, in all tumor samples. Levels were comparable with those of EPT, a tumor group known to have a strong expression of SV2 protein.

Previous reports have demonstrated expression of peptide hormone receptors on both interstitial cells of Cajal and GISTs. The presence of immunoreactivity for both ghrelin and its receptor indicates a possible autocrine/paracrine loop. Co-expression of the hormone and its receptor has been shown in several tumor types, including pancreatic adenocarcinoma and EPT (Jeffery et al. 2003). Ghrelin has been shown to increase proliferation and invasiveness in a pancreatic adenocarcinoma cell line expressing the ghrelin receptor (Duxbury et al. 2003). In the present study of a limited patient material, we did not find any correlation between the expression of ghrelin and its receptor and malignant features (e.g. tumor size, highrisk score, KIT exon 11 mutations, or disseminated disease). Larger numbers of GISTs may be necessary to address this important question.

We found ghrelin immunoreactivity in the cytoplasm with a fine granular pattern. In several tumor samples, the staining was heterogeneous with large areas devoid of ghrelin immunoreactivity and other parts with strong staining. The highly sensitive qPCR method revealed ghrelin mRNA in all examined GISTs, whereas IHC showed ghrelin reactivity in $77 \%$. The PCR revealed mean ghrelin levels clearly above those of 


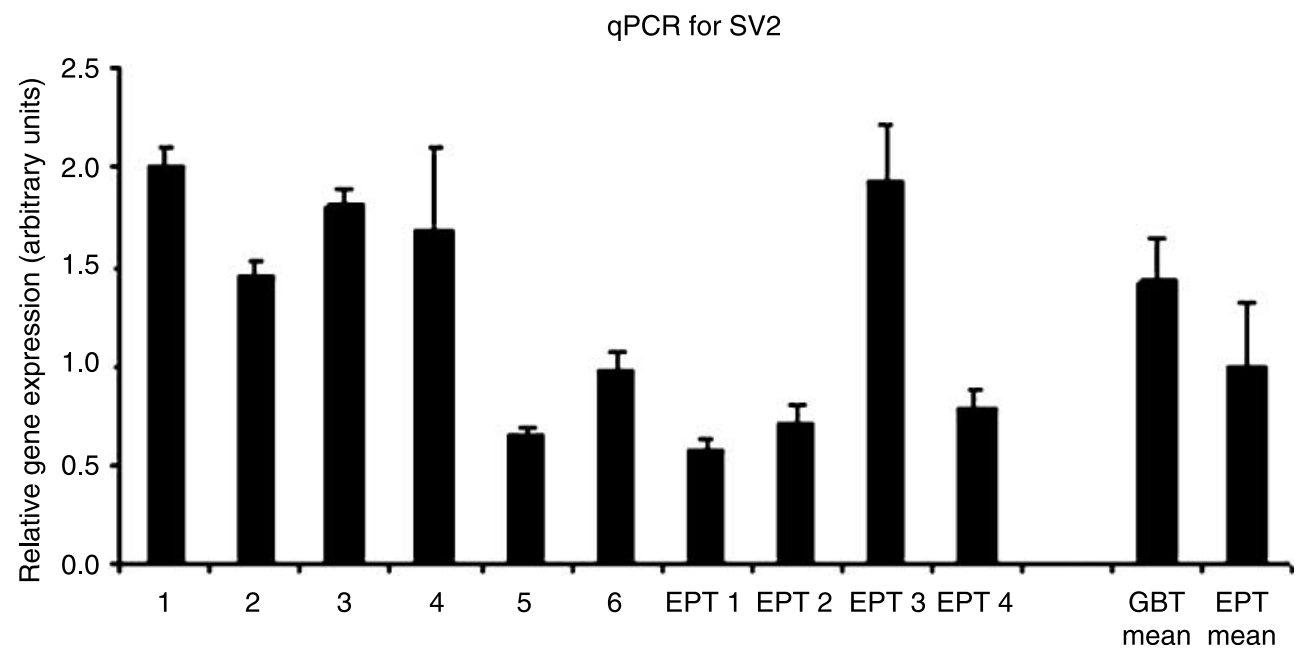

Figure 3 Mean relative gene expression of SV2 determined with real-time qPCR, \pm S.E.M. High levels were found in all six analyzed lesions. The mean SV2 mRNA level in GIST tumors was similar to that of EPTs 1-4 used as controls.

one immunohistochemically negative EPT and one with few ghrelin reactive cells. Two GISTs had levels similar to controls. The discrepancy between RNA levels and protein expression might be due to the observed heterogenous distribution of ghrelin within each single sample. It could also be due to a variable degree of translation of the protein. An alternative interpretation could be that the protein is produced, but not stored, in individual tumors.

A similar expression pattern was seen for the ghrelin receptor; mRNA was revealed in all analyzed tumors, but only $50 \%$ showed immunoreactivity. One tumor had mRNA levels much higher than any of the EPT used as controls; all tumors expressed receptor mRNA at levels comparable to or even higher than the mean levels of the EPT.

Patients with GIST seldom suffer from cancer cachexia, even in advanced disease. In the present limited series of GIST patients, we could record a mean BMI of 25.1 (25.4 in patients with ghrelin-immunoreactive tumors), which shows that these patients did not suffer from cancer cachexia, despite a majority of patients presenting with large tumors $(>10 \mathrm{~cm} ; 8 / 14)$, high Fletcher risk score (12/14), and distant metastases (7/14). A more comprehensive patient material would be needed to statistically correlate ghrelin immunoreactivity to BMI. The BMI of our patients in the present paper indicates that GIST patients follow the trend of prevalent overweight presently seen in Sweden (Sundquist et al. 2004). Endogenous secretion of the potent orexigen ghrelin from the tumor might contribute to the relative well-being of these patients.
However, the analysis of circulating ghrelin levels is lacking in the present retrospective study. A more comprehensive metabolic evaluation of GIST patients in a prospective study design would be of great interest.

\section{Conclusion}

GISTs frequently express SV2, as well as the orexigenic hormone ghrelin and its receptor, indicating the presence of an autocrine/paracrine loop.

\section{Funding}

This work was supported by the Swedish Cancer Society, the Lion's Cancer Research Foundation, and the Swedish Research Council. There is no conflict of interest.

\section{References}

Beckers MM, Slee PH \& van Doorn J 2003 Hypoglycaemia in a patient with a gastrointestinal stromal tumour. Clinical Endocrinology (Oxf) 59 402-404.

Bumming P, Andersson J, Meis-Kindblom JM, Klingenstierna H, Engstrom K, Stierner U, Wangberg B, Jansson S, Ahlman H, Kindblom LG et al. 2003 Neoadjuvant, adjuvant and palliative treatment of gastrointestinal stromal tumours (GIST) with imatinib: a centre-based study of 17 patients. British Journal of Cancer $\mathbf{8 9}$ 460-464.

Bumming P, Nilsson B, Sorensen J, Nilsson O \& Ahlman H 2006 Use of 2-tracer PET to diagnose gastrointestinal 
stromal tumour and pheochromocytoma in patients with Carney triad and neurofibromatosis type 1. Scandinavian Journal of Gastroentrology 41 626-630.

Carney JA, Sheps SG, Go VL \& Gordon H 1977 The triad of gastric leiomyosarcoma, functioning extra-adrenal paraganglioma and pulmonary chondroma. New England Journal of Medicine 296 1517-1518.

Corbetta S, Peracchi M, Cappiello V, Lania A, Lauri E, Vago L, Beck-Peccoz P \& Spada A 2003 Circulating ghrelin levels in patients with pancreatic and gastrointestinal neuroendocrine tumors: identification of one pancreatic ghrelinoma. Journal of Clinical Endocrinology and Metabolism 88 3117-3120.

Corless CL, Fletcher JA \& Heinrich MC 2004 Biology of gastrointestinal stromal tumors. Journal of Clinical Oncology 22 3813-3825.

De Ambrogi M, Volpe S \& Tamanini C 2003 Ghrelin: central and peripheral effects of a novel peptydil hormone. Medical Science Monitor 9 RA217-RA224.

DeMatteo RP, Lewis JJ, Leung D, Mudan SS, Woodruff JM \& Brennan MF 2000 Two hundred gastrointestinal stromal tumors: recurrence patterns and prognostic factors for survival. Annals of Surgery 231 51-58.

Duxbury MS, Waseem T, Ito H, Robinson MK, Zinner MJ, Ashley SW \& Whang EE 2003 Ghrelin promotes pancreatic adenocarcinoma cellular proliferation and invasiveness. Biochemical and Biophysical Research Communications 309 464-468.

Fletcher CD, Berman JJ, Corless C, Gorstein F, Lasota J, Longley BJ, Miettinen M, O’Leary TJ, Remotti H, Rubin BP et al. 2002 Diagnosis of gastrointestinal stromal tumors: A consensus approach. Human Pathology 33 459-465.

Fukasawa T, Chong JM, Sakurai S, Koshiishi N, Ikeno R, Tanaka A, Matsumoto Y, Hayashi Y, Koike M \& Fukayama M 2000 Allelic loss of 14q and 22q, NF2 mutation, and genetic instability occur independently of c-kit mutation in gastrointestinal stromal tumor. Japanese Journal of Cancer Research 91 1241-1249.

Heid CA, Stevens J, Livak KJ \& Williams PM 1996 Real time quantitative PCR. Genome Research 6 986-994.

Hirota S, Isozaki K, Moriyama Y, Hashimoto K, Nishida T, Ishiguro S, Kawano K, Hanada M, Kurata A, Takeda M et al. 1998 Gain-of-function mutations of c-kit in human gastrointestinal stromal tumors. Science 279 577-580.

Iwakura H, Hosoda K, Doi R, Komoto I, Nishimura H, Son C, Fujikura J, Tomita T, Takaya K, Ogawa Y et al. 2002 Ghrelin expression in islet cell tumors: augmented expression of ghrelin in a case of glucagonoma with multiple endocrine neoplasm type I. Journal of Clinical Endocrinology and Metabolism 87 4885-4888.

Jakobsen AM, Ahlman H, Wangberg B, Kolby L, Bengtsson M \& Nilsson O 2002 Expression of synaptic vesicle protein 2 (SV2) in neuroendocrine tumours of the gastrointestinal tract and pancreas. Journal of Pathology 196 44-50.
Jeffery PL, Herington AC \& Chopin LK 2003 The potential autocrine/paracrine roles of ghrelin and its receptor in hormone-dependent cancer. Cytokine and Growth Factor Reviews 14 113-122.

Kindblom LG, Remotti HE, Aldenborg F \& Meis-Kindblom JM 1998 Gastrointestinal pacemaker cell tumor (GIPACT): gastrointestinal stromal tumors show phenotypic characteristics of the interstitial cells of Cajal. American Journal of Pathology 152 1259-1269.

Nilsson B, Bumming P, Meis-Kindblom JM, Oden A, Dortok A, Gustavsson B, Sablinska K \& Kindblom LG 2005 Gastrointestinal stromal tumors: the incidence, prevalence, clinical course, and prognostication in the preimatinib mesylate era-a population-based study in western Sweden. Cancer 103 821-829.

Patterson LM, Zheng H, Ward SM \& Berthoud HR 2001 Immunohistochemical identification of cholecystokinin A receptors on interstitial cells of Cajal, smooth muscle, and enteric neurons in rat pylorus. Cell and Tissue Research 305 11-23.

Portela-Gomes GM, Lukinius A \& Grimelius L 2000 Synaptic vesicle protein 2, a new neuroendocrine cell marker. American Journal of Pathology 157 1299-1309.

Reubi JC, Korner M, Waser B, Mazzucchelli L \& Guillou L 2004 High expression of peptide receptors as a novel target in gastrointestinal stromal tumours. European Journal of Nuclear Medicine and Molecular Imaging 31 803-810.

Rindi G, Torsello A, Locatelli V \& Solcia E 2004 Ghrelin expression and actions: a novel peptide for an old cell type of the diffuse endocrine system. Experimental Biology and Medicine (Maywood) 229 1007-1016.

Sarlomo-Rikala M, Kovatich AJ, Barusevicius A \& Miettinen M 1998 CD117: a sensitive marker for gastrointestinal stromal tumors that is more specific than CD34. Modern Pathology 11 728-734.

Sternini C, Wong H, Wu SV, de Giorgio R, Yang M, Reeve J Jr, Brecha NC \& Walsh JH 1997 Somatostatin 2A receptor is expressed by enteric neurons, and by interstitial cells of Cajal and enterochromaffin-like cells of the gastrointestinal tract. Journal of Comparative Neurology 386 396-408.

Sundquist K, Qvist J, Johansson SE \& Sundquist J 2004 Increasing trends of obesity in Sweden between 1996/97 and 2000/01. International Journal of Obesity and Related Metabolic Disorders 28 254-261.

Tschop M, Smiley DL \& Heiman ML 2000 Ghrelin induces adiposity in rodents. Nature 407 908-913.

Volante M, Allia E, Gugliotta P, Funaro A, Broglio F, Deghenghi R, Muccioli G, Ghigo E \& Papotti M 2002 Expression of ghrelin and of the GH secretagogue receptor by pancreatic islet cells and related endocrine tumors. Journal of Clinical Endocrinology and Metabolism 87 1300-1308. 